\title{
2
}

\section{Social Change and Rediscovering Rural Reconstruction in China ${ }^{1}$}

\author{
Ou Ning
}

\section{The Origins of the Rural Reconstruction Movement}

Rural reconstruction, one of the most important insurmountable problems in China's relentless pursuit of modernity, has had its ups and downs over the last 100 years. It again has emerged as a lens through which to examine the role of different political and intellectual forces in China's process of social reform. This chapter explores this historical legacy and the recent re-emergence of rural reconstruction as a source of inspiration for Chinese social change.

Chinese elites began exploring the concept of rural reform in the late Qing dynasty, when Mi Jiansan and his Japan-educated son Mi Digang, members of a distinguished local family in the village of Zhaicheng in Ding county of Hebei province, experimented with the idea of 'village government' (cunzhi 村治) in 1902, through literacy campaigns, civic education and local self-government. County magistrate Sun Faxu developed their idea further as he took the post of governor in neighbouring Shanxi province, and it was later also embraced by the

1 This chapter is a revised version of an essay first published in Ou Ning ed., The South of Southern: Space, Geography, History and the Biennale (Beijing: China Youth Press, 2014). 
warlord Yan Xishan, who effectively controlled Shanxi in the Republican era and turned the province into a model of rural reconstruction. The 'Village Government Group' (cunzhipai 村治派) was established as a school of thought in 1924, when some north China landed gentry, including Wang Hongyi, Mi Digang, Mi Jieping, Peng Yuting, Liang Zhonghua, Yi Zhongcai and Wang Yike, launched the Zhonghua Daily (Zhonghua ribao 中华日报) and the Village Government Monthly (Cunzhiyuekan 村治月刊). In 1925, the then four-year-old Chinese Communist Party, having realised the importance of farmers to its revolution, decided to mobilise support in the countryside with their 'Letter to Farmers' (gao nongmin shu 告农民书), encouraging the establishment of farmers' unions. The ensuing class struggles and land revolution provoked urban intellectuals into seeking different approaches to rural reform.

The 30 May 1925 shooting of protesters in the Shanghai International Settlement sparked a nationwide labour and anti-imperialist movement, and many parts of China saw a surge of rural reconstruction experiments. By 1934, official statistics show that there were more than 600 rural reconstruction groups and over 1,000 experiments across China. ${ }^{2}$ Newspapers and magazines were filled with reports, commentaries and debates on rural reconstruction. The two most influential experiments were those conducted by Liang Shuming's Rural Reconstruction Institute in Zouping county, Shandong province, and Y. C. James Yen's Mass Education Association in Ding county, Hebei province. Liang, inspired by the 'Village Government Group', developed a Confucianism-based philosophy for rural reconstruction and thus was considered a member of the 'Old Group' (jiupai 旧派) while Yen, who was Christian and received funding from the United States, belonged to the 'New Group' (ximpai 新派).

\section{The Politics of Rural Reconstruction}

In the 13th volume of The Cambridge History of China, historian John K. Fairbank devoted a whole section, 'The Rural Reconstruction Movement', to the massive rural reconstruction campaigns of the time. Fairbank

2 Zhang Yuanshan and $\mathrm{Xu}$ Shilian eds, Xiangcun jianshe shiyan [Experiment of Rural Reconstruction] Volume 2, (Shanghai: Zhonghua Book Company, 1935), 19. 
identified six types of campaigns: 1) Western-influenced (James Yen); 2) nativist (the 'Village Government Group', Liang Shuming and Tao Xingzhi, the founder of the Xiaozhuang Normal College in Nanjing); 3) educational (James Yen and Tao Xingzhi); 4) military (Peng Yuting, who established a local defence regime in Zhenping county, Henan province); 5) populist (James Yen and Tao Xingzhi); and 6) bureaucratic (the two 'experimental counties' administered by the Nanjing authorities in Lanxi, Zhejiang province and Jiangning, Jiangsu province). But Fairbank's volume overlooked several other important experiments-those carried out by $\mathrm{Lu}$ Zuofu's Chongqing Beibei Defence Bureau in the Gorges region along the Yangtze tributary Jialing River; Gao Jiansi's Jiangsu Provincial Institute of Education in Huangxiang, Wuxi, Jiangsu province; and Huang Yanpei's National Association of Vocational Education of China in Xugongqiao, Kunshan, Jiangsu province.

The Cambridge History of China stated that all rural reconstruction experiments were linked inextricably to politics:

To revitalise the countryside through educational and economic reforms meant working out relationships of patronage and protection with political authorities. This was surely because any attempt to work with the peasantry in an organised project inevitably raised questions of political orientation and legitimacy, whether or not the project had any explicitly political aims or activities. ${ }^{3}$

Owing to political uncertainty, these educational, social and economic reforms - though not without a local effect-were unable to provide a comprehensive solution to China's rural problems. Politics was not only a barrier to China's rural reconstruction but a key factor contributing to its ultimate failure. Yen first claimed that his experiment had nothing to do with politics, but had to admit later that 'given the circumstances, we couldn't keep ourselves away from politics'. ${ }^{4}$ Liang said that the 'two major difficulties' he encountered were 'the inevitable need to rely on the

3 Philip A. Kuhn, 'The Rural Reconstruction Movement', in John K. Fairbank and Albert Feuerwerker eds, The Cambridge History of China, vol. 13, Republican China 1912-1949, Part 2 (Cambridge: Cambridge University Press, 1986), 359.

4 Y. C. James Yen, 'Pingmin jiaoyu yundong de huigu yu qianzhan' [The Past and Future of the Mass Education Movement], in Enrong Song ed., Gaoyu renmin [To the People] (Guilin: Guangxi Normal University Press, 2003), 197. 
authorities to push for social reform and farmers' indifference to the rural reconstruction movement'. ${ }^{5}$ Rural reconstruction was doomed to failure if it did not seek 'a political solution'. ${ }^{6}$

In fact, the multitude of experiments that focused on local selfgovernment, mass education and agricultural development were preceded by the brief existence in China of a utopian philosophy called 'New Village-ism' (xincunzhuyi 新村主义)—a mixture of Japanese writer Mushanokōji Saneatsu's idea of Atarashiki-mura (New Village, 新しき村), Peter Kropotkin's theory of mutual aid, and Lev Tolstoy's view of labour and the North American practice of combining studies with part-time work. Mushanokōji's philosophy was part of the 'White Birch Group' (Shirakaba-ha 白樺派), for the name of the literary magazine he founded in 1910, 'White Birch' (on this movement see also Chapters One and Three). In 1918, in the mountains of Miyazaki Prefecture in Kyushu, members of the White Birch Group carried out their plan to build an intentional community without government, exploitation or social class and to live an idyllically pastoral life. Chinese writer Zhou Zuoren was a long-time subscriber to the commune's literary magazine Atarashiki-mura, expressing his support for the movement in his articles 'Humanist Literature' (Rende wenxue 人的文学) and 'Japan's New Village' (Ribende xincun 日本的新村), published in 1918 and 1919 in the influential magazine La Jeunesse, during China's New Culture Movement of the 1910s and 1920s. Zhou even visited Miyazaki himself and in 1920 founded a branch of the Atarashiki-mura commune in his Beijing home, attracting early communist leaders such as Li Dazhao, Mao Zedong, Cai Hesen and Yun Daiying.

The same year, a similar and influential experiment was started in the village of Xiaowuying of Xihua county, Henan province, by Wang Gongbi, a member of the former Tongmenghui, a revolutionary alliance absorbed by the Kuomintang in 1912. Xiaowuying was soon renamed Youth Village (qingniancun 青年村). Mao Zedong was also an admirer of 'New Village-ism', but chose the path of revolution in the end. It was only after the founding of the People's Republic of China in 1949 that

5 Liang Shuming, Xiangcun jianshe lilun [Rural Reconstruction Theories] (Shanghai: Shanghai Century Publishing Group, 2006), 368.

6 Cao Lixin made an in-depth analysis of the political dilemma faced by the rural reconstruction movement in the Republican era in comparison with the rural revolution of the Communist Party of China. See Cao Lixin, 'Zouxiang zhengzhi jiejue de xiangcun jianshe' [Rural Reconstruction: Toward a Political Solution], Twenty-First Century 91 (October 2005). 
Mao would transform this utopian philosophy into people's communes. The idealistic values of 'New Village-ism', unlike the pragmatic approach of the rural reconstruction movement, soon fell into decline in China. In fact, 'New Village-ism' was not only a Japanese import but a continuation of ancient Chinese Agrarianism (nongjia 农家), the most marginalised and overlooked of all the schools of thought, and one that dates back to the golden age of Chinese philosophy from 770 to 221 BC. Agriculturalism was discussed in a volume ('Treatise on Literature', yiwenzhi 艺支志) of the Book of Han (hanshu 汉书), a history written in the Han dynasty:

The first Agrarianists may have been agriculture officials, who grew different kinds of grain and encouraged people to till land and plant mulberry trees to produce enough food and clothing. Food is so important that it ranks first among the eight major areas of a state's policy, followed by property. The merit of early Agriculturalists is their emphasis on food production, which Confucius said should be a priority for any ruler. However, their vulgar successors, who believe that a saint-king in the Confucian sense would be useless, attempt to disrupt the social hierarchy by calling on rulers to plough alongside their people.

In his book Debt: The First 5000 Years, American anthropologist and anarchist David Graeber referred to Agrarianism as an anarchist movement in the pre-Qin period. ${ }^{7}$

\section{Crisis and Revival}

The rural reconstruction movement turned out to be short-lived as well. Reformers saw their hopes crushed in 1937, when the national crisis following Japan's invasion took precedence over rural impoverishment and decline as the most urgent problem faced by the country. Still, had the war not broken out, the rural reconstruction movement would have eventually failed because of its own limitations. In 1930, Peng Yuting was assassinated by a rival faction and Chiang Kai-shek ordered Tao Xingzhi to close his Xiaozhuang Normal College. Wang Dazhi, one of Tao's students,

7 'In China, while many of the founders of the "hundred schools" of philosophy that blossomed under the Warring States were wandering sages who spent their days moving from city to city trying to catch the ears of princes, others were leaders of social movements from the very start. Some of these movements didn't even have leaders, like the School of the Tillers, an anarchist movement of peasant intellectuals who set out to create egalitarian communities in the cracks and fissures between states.' David Graeber, Debt: The First 5000 Years (New York: Melville House, 2012), 237. 
carried on the work of his alma mater after being appointed principal of the Xin'an Primary School. He organised the Xin'an Traveling Group (xinan luxingtuan 新安旅行团), whose students spent more than 10 years visiting different parts of China and calling for resistance to the Japanese invasion. As different political forces joined the resistance movement, Liang Shuming's Shandong Rural Reconstruction Institute was disbanded and James Yen's Mass Education Association moved to Chongqing with the Kuomintang Government. But Yen did not give up his rural reform efforts. In Chongqing, he established the Chinese Institute of Rural Reconstruction, which was declared a 'reactionary organisation' and taken over by the local Military Control Commission in 1950. Nevertheless, his International Institute of Rural Reconstruction, founded in 1960 in the Philippines, still operates today. Yen dedicated his whole life to rural reconstruction.

These reformers were often criticised for their superficial understanding of the complexity of Chinese society, especially China's stubborn social problems. In 1936, the New Knowledge Bookstore (Xinzhi Shudian 新 知书店) published Critiques of China's Rural Reconstruction (Zhongguo xiangcun jianshe pipan 中国乡村建设批判), a collection of commentaries on Liang's and Yen's experiments written by pro-Communist intellectuals such as Qian Jiaju and Li Zixiang. Qian pointed out that Yen and his associates did not fully understand Chinese society:

They attribute China's social ills to the ignorance, poverty, weakness and selfishness of farmers, who account for over 85 percent of China's population, and believe they need to address those four problems to save Chinese society. But they overlook the fact that farmers' ignorance, poverty, weakness and selfishness are only the symptoms of China's social ills. The root cause cannot be removed simply by treating the symptoms. ${ }^{8}$

Qian argued that Liang, as a 'rural philosopher', had a more in-depth understanding of Chinese society than Yen, but offered only an old solution repackaged as a new one:

Mr. Liang's new approach appears to be a perfect solution that could immediately lead people into 'a kingdom of liberty, equality and fraternity'. But that is actually just an old trick invented by Confucius, who once said, 'The people only need to be told what to do but not why

8 Qian Jiaju, 'Zhongguo nongcun jianshe zhi lu hezai' [Where Is the Path to China's Rural Reconstruction?], in Zhongguo xiangcun jianshe pipan [Critiques of China's Rural Reconstruction] (Shanghai: New Knowledge Bookstore, 1936), 101. 
they should do it'. His theories of rural reconstruction, under the new disguise of farmer organisations and farmer education, are nothing more than a clever redesign of the current social order. ${ }^{9}$

These two kinds of experiments, Qian suggested, would lead China astray. Although he did not put forward any feasible solution in his articles, it can be inferred from his arguments that he advocated anti-imperialist, anti-feudal class struggles aimed at subverting the established system. The theory of class struggle also served as the ideological basis for the Chinese Communist Party's revolution.

If the only viable option for the Communist Party at that time was to seize power through revolution, what would it do about the unresolved issue of rural reconstruction after its revolution succeeded? Shortly after the People's Republic of China was founded in 1949, private ownership was abolished in the countryside through the agricultural cooperative movement. People's communes were introduced in 1958 as a quintessential example of Mao's vision of rural reconstruction. The concept of people's communes is a blend of the utopian 'New Villageism', Liang Shuming's theory of combining politics with education, and Peng Yuting's military-style management. Land and labour were pooled to boost agricultural production so that China could build a communist society, in which people would work to their best ability and have all their needs satisfied. However, before being gradually dismantled by the new market economy created in 1984, the communes did not bring about any fundamental improvement in the rural economy or farmers' lives. Instead, they severely damaged Chinese rural society. The concentration of land and other means of production disrupted traditional small-scale farming; intense class struggles and frequent political movements destroyed the family structure and ethics in rural areas; forced labour and egalitarianism demoralised farmers.

Thanks to the household responsibility system adopted in 1982, rural China was revitalised temporarily. But the fast-growing urbanisation that followed has left the countryside increasingly deprived and marginalised and has given rise to myriad problems, including agricultural decline, the loss of agrarian land, rural emigration, reliance on imported food, poor land-use planning (new homes are mostly built on the periphery of a village, leaving the centre with abandoned, dilapidated houses),

9 Qian Jiaju, 'Zhongguo de qilu' [China’s Wrong Road], in Zhongguo xiangcun jianshe pipan (Critiques of China's Rural Reconstruction) (Shanghai: New Knowledge Bookstore, 1936), 142. 
insufficient public resources, local gangs, rural-urban imbalance and social conflicts, especially the numerous mass protests staged against arbitrary land acquisitions by the government. Rural reconstruction has re-emerged as a critical issue for China.

In 2003, researcher Wen Tiejun, who coined the phrase 'three rural problems' (rural people, rural society and the rural economy, sannong wenti 三农问题), founded the James Yen Rural Reconstruction Institute at the village of Zhaicheng of Hebei province, where Mi Jiansan, Mi Digang and James Yen had done their pioneering work. ${ }^{10}$ Farmers from all parts of China arrived at Zhaicheng to participate in his project, which generated significant media coverage. In 2004, Wen was appointed Dean of the School of Agricultural Economics and Rural Development at Remin University in Beijing. He also founded the Liang Shuming Rural Reconstruction Center, a branch of which he moved to Renmin in 2005. The founding of this research institute with multiple affiliate organisations suggested a considerable revival of the rural reconstruction movement of the Republican era. The same year, the Fifth Plenum of the 16th Central Committee of the Communist Party of China resolved to create a 'new socialist countryside' (shehuizhuyixin nongcun 社会主义新农村) to address the 'three rural problems'. As Wen and other intellectuals became more involved in rural reconstruction in different parts of the country, governments of all levels were ready to implement the Party's new policy. For example, Sichuan province and Chongqing municipality launched experimental projects to coordinate rural and urban development. The issue of rural reconstruction returned to public view, attracting the attention of both the government and civil society.

Wen was sent to live and work in rural Shanxi province during the Cultural Revolution. He went to Renmin University to study journalism in 1979 and joined the Rural Policy Research Office of the Party's Central Committee in 1985, where he assisted Du Runsheng, an important promoter of the household responsibility system, in research and fieldwork. Thus he gained first-hand experience of the hardships of rural life. Wen studied at the University of Michigan in 1987 and at Columbia University in 1991. He visited Cornell University and the University of

10 All quotations from Wen Tiejun in this chapter are taken from 'Sannong wenti: shiji mo de fansi' [The Three Rural Problems: Some Reflections at the End of the Twentieth Century], Dushu, December 1999. For the longer version of this article, see Tiejun Wen, Sannong wenti yu shiji fansi [The Three Rural Problems and Some Reflections at the End of the Twentieth Century] (Beijing: Joint Publishing, 2005). 
Southern California as a visiting scholar in 1991. However, compared with James Yen, who also received Western academic training and embraced an international perspective, Wen has been able to make more insightful observations about the 'three rural problems' and put forward theories in a broader context by using the research methodology he learned from the distinguished economist Wu Jinglian.

Familiar with the philosophy behind the rural reconstruction movement of the Republican era and the rural revolution of the Communist Party, Wen argues that owing to China's enormous population and limited available land, 'neither the revolution nor the reform led to anything other than "equal" distribution of arable land'. He believes that the main cause of the social conflicts in rural areas, unknown to his predecessors, is the excessive extraction of agricultural surplus, which undermines 'the property and income distribution system inherent in the small-scale peasant economy'. That system, in his opinion, is the norm and a stabilising factor for Chinese society, and is 'naturally resistant to the Western Industrial Revolution and the ensuing "social progress" in the capitalist sense'. Wen asserts that China, like the West, has been passing on the huge institutional costs of industrialisation and urbanisation to its countryside.

He also believes that China's development strategy, oriented toward industrial capital, international trade and economic globalisation, not only has imposed an onerous burden on farmers, rural society and agriculture but involves significant risk itself because excessive dependence on imported food and resources means potential vulnerability to global shocks, especially financial crises. Wen often says in self-mockery that his attitude toward urbanisation is too 'conservative' but, in a country obsessed with urban life and high economic growth, his commitment to rural reconstruction is more likely to be considered radical. Compared with the pioneers in the Republican era, he has accomplished more with fewer resources. But he has encountered the same problem as his predecessorslocal authorities shut down the James Yen Rural Reconstruction Institute in 2006 on the grounds that it had built an environmentally friendly building without official approval, missed the annual inspection by the local government and advised farmers on petition matters.

Nevertheless, Wen and his followers are as resilient as James Yen. After the institute was closed, Qiu Jiansheng, who had joined the cause of rural reconstruction because of Wen, launched new projects in Hainan and Fujian provinces. One of Wen's PhD students, He Huili, continued to 
work as assistant to the mayor of Kaifeng city, Henan province, and help local farmers form cooperatives. The Liang Shuming Rural Reconstruction Center is still in operation, encouraging university students to do their part for rural reconstruction, though its former director Liu Xiangbo died in a car accident in 2011. The Little Donkey Farm in the western suburbs of Beijing is working on ecological agriculture and devising new methods to provide organic produce for city dwellers. They all have benefitted from Wen's theories and support, sharing resources among themselves. ${ }^{11}$ In addition to Wen's movement, there are other important projects such as the ones run by He Xuefeng in Hubei province, Li Changping in Henan province and Liao Xiaoyi in Sichuan province. By combining the traditional approach to rural reconstruction focused on mass education and agriculture with their insights into contemporary problems, these people have developed various new programs and concepts such as community colleges, community-supported agriculture, ecological villages and 'Workers' Homes', programs targeting migrant workers living in cities (gongyouzhijia 工友之家).

Many urban writers and artists have settled in the countryside and become involved in the rural reconstruction movement either because they have noticed the inextricable link between rural and urban areas or because they aspire to rediscover and revive the traditional culture eroded by urbanisation. A well-known example is Johnson Chang Tsong-zung and $\mathrm{Hu}$ Xiangcheng's project in the small town of Jinze near Shanghai. They transformed an abandoned industrial site there into a village featuring architecture typical of traditional buildings in the region. Their project covers a number of areas, including reviving traditional folk arts, developing organic farming (they are running a farm as part of the project) and restoring traditional values. ${ }^{12}$ Other examples include writer Ye Fu's experiment in representative democracy and rural drama in Luojiang county, Sichuan province, and Li Yinqiang's China Rural Library, a non-government organisation (NGO) that often invites urban writers and intellectuals to give talks to rural children. The strength of these projects lies in their ability to leverage the unique cultural resources at their disposal. ${ }^{13}$

11 For more information about the rural reconstruction movement led by Wen Tiejun, see Hong Liang, 'Xingdong zai dadi' [Action on Land], Chutzpah!, January 2011.

12 Australian writer Tony Perrottet visited and wrote about Jinze. See Tony Perrottet, 'The Shock of the Old', The Wall Street Journal Magazine, 28 June 2012, online.wsj.com/article/SB1000142405270 2304765304577482580429791656.html.

13 For more information about these projects, see 'Tamen de xiangjian' [Their Rural Reconstruction], in ChinaFortune, November 2011. 
China's urban-rural relations first came to my attention when I was doing research and making documentary film in Guangzhou's urban village San Yuan Li from 2002 to 2003. I realised that urban villages and slums were actually rooted in the failure of the rural economy. From then on, I became interested in studying rural issues, learned about Wen Tiejun's theories and work, and read the biography of James Yen as well as works on the rural reconstruction movement of the Republican era. Before starting my own project, the Bishan Commune (Bishan Gongtongti 碧山共同体), in the village of Bishan of Yi county, Anhui province, in 2011, I spent years studying rural society and social movements. I visited the closed James Yen Rural Reconstruction Institute, Qiu Jiansheng's project in Fujian and He Huili's workplace in Henan. I attended the 'Ecology and the Revival of Rural Culture' seminar hosted by Wen Tiejun, talked with intellectuals engaged in rural movements in Taiwan, and examined the diverse body of literature on Chinese rural society.

I also watched Ogawa Shinsuke's documentaries about rural Japan, visited Thai artists Rirkrit Tiravanija and Kamin Lertchaiprasert's Land Foundation in Chiang Mai, and read about Indian writer Arundhati Roy's criticism of the controversial Narmada Dam project and of the Indian Government's armed actions against the Maoist insurgents supported by rural populations. My Bishan Commune thus turned out to be a melting pot of fascinating ideas-a mixture of the benevolent society described in Peter Kropotkin's Mutual Aid: A Factor of Evolution, the concept of 'direct action' advocated by neo-anarchism, the utopian artist collective Neue Slowenische Kunst established by Slovenian artists, the rural reconstruction movement of the Republican era, and the vision of contemporary reformers like Wen Tiejun.

\section{The Bishan Project}

In 2011, Zuo Jing and I purchased two antique Hui-style houses in the villages of Bishan and Guanlu of Yi County to start our project. We raised funds to hold the first Bishan Harvestival (bishan fengnianij 碧山丰年祭), a cultural feast in the form of a harvest celebration. Based on a project called 'Craftsmanship in Yi County' (yixian baigong 黟县百工), the event invited artists, architects and designers from other parts of the country to work with local craftsmen and folk artists to create modern versions of traditional objects, which were put on display in 
Bishan's ancestral halls and old granaries. There were also exhibitions of historical documents about Bishan village and the region, performances by musicians from other places and local Chinese opera groups, poetry classes for local children, the screening of documentary and dramatic films about rural China, seminars on rural reconstruction attended by participants from both mainland China and Taiwan, and farmers' fairs. ${ }^{14}$

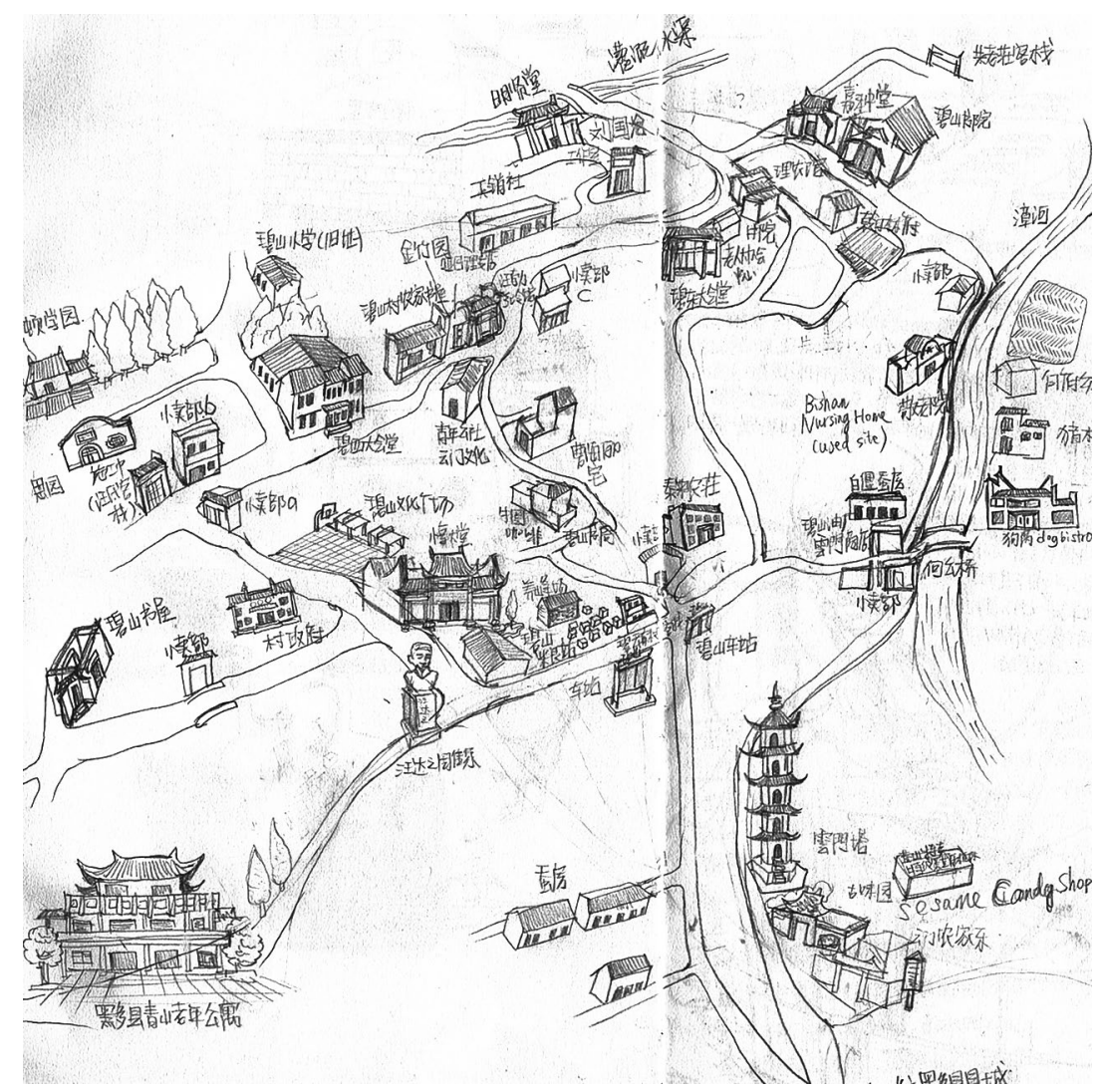

Figure 1: Schematic image of Bishan community.

Source: Ou Ning.

14 For details about the Bishan Harvestival, see Zhao Qian's report in the October 2011 issue of Leap. 
As the first step of our plan, the Bishan Harvestival (a portmanteau of the words 'harvest' and 'festival') aimed at reinvigorating public life in rural areas. We believed that reviving traditional folk arts was, at that stage, the only way to transform our cultural resources into job opportunities and tangible economic benefits for farmers because, although Bishan attracts many tourists every year thanks to its proximity to the beautiful Mount Huangshan, its heavy reliance on admission charges to generate tourism revenue may be unsustainable. However, we hoped that the Bishan Commune would go beyond arts and culture and take on economic and social dimensions by encouraging farmers to engage in 'exchange of labour' (jiaogong 交工), for example, and through other forms of mutual aid so that they can depend less on public services.

My own project in Bishan gave me a deeper understanding of the difficulties of rural reconstruction. First of all, since the Republican era, rural reconstruction, as a spontaneous movement independent of the government, always has faced a major constraint—its legitimacy and social space depend on its delicate relationship with politics. Any misstep can lead to failure, as in the examples of Tao Xingzhi's Xiaozhuang Normal College, Peng Yuting's experiment in Zhenping and Wen Tiejun's James Yen Rural Reconstruction Institute. So we need to be cautious about engaging local authorities ourselves and avoid compromising the independence and sustainability of the Bishan Commune when seeking the government's support. The second thing that I learnt from this project is that, although rural reconstruction needs financing, corporate and government funds would undermine the movement's independence while funding from the general public is inadequate at this time and will not be a viable source of financing without persistent effort. James Yen received funding from the Rockefeller Foundation but was criticised for relying on 'imperialism'. His case, though successful in a sense, was an exception that cannot serve as an example to everyone. A fundamental element of Wen Tiejun's rural reconstruction philosophy is his disapproval of 'big capital'. Wen refuses funding from large corporations and even NGOs, which means that his colleagues may be doing their work for its own sake without any material reward. At the Bishan Commune, we secured the necessary funding by including our programs in the budgets of the large arts exhibitions and events we are commissioned to organise, paying from our own pockets or asking our friends for donations. None of these methods, nevertheless, is sustainable. 
Third, local communities' understanding of rural reconstruction is sometimes at odds with the lofty ideals of intellectuals. Local people seldom recognise the value of outsiders' work if they don't perceive any practical benefits. Some of them even become your enemies if other groups are helped at their expense. For example, cotton farmers in Ding county were grateful to James Yen because the cooperatives he helped to form made it unnecessary for them to borrow from banks or through intermediaries and thus reduced their costs. But, as a result, many local banks went bankrupt. Failed banks laid siege to Yen's Mass Education Association and demanded it leave the county. Similarly, we found it both amusing and frustrating when some villagers called the Bishan Harvestival, which was free to all local farmers, a profitable investment in tourism. ${ }^{15}$

So why bother engaging in rural reconstruction if it is so difficult? Wen once said, 'Personally, it's because I can't stand doing nothing about it. Humans, particularly intellectuals, inevitably possess a feminine kindness. If intellectuals, as part of the social mainstream, didn't have that quality or didn't reflect on this issue, the social mainstream would be a masculine one or, in other words, would have a tendency toward extreme beliefs'. ${ }^{16}$ As a man who was born in rural China, struggled to find his footing in the city and then aspired to return to the countryside, I do not sense in Wen's words any condescension but a genuine compassion for his fellow Chinese.

15 Editors' note: In the first half of 2016, the Chinese authorities cut off the electricity and water supply and closed the main cultural centre that Ou Ning had established in Bishan, forcing Ou to leave the village, though the ideals of the project appear to live on in many aspects of village life; see Calum Macleod, 'Crushed Dreams of Utopia in Rural China', The Times, 2 May 2016.

16 Hong Liang, 'Xingdong zai dadi,' [Action on Land] Chutzpah!, January 2011. 
This text is taken from New Worlds from Below: Informal life politics and grassroots action in twenty-first-century Northeast Asia, edited by Tessa Morris-Suzuki and Eun Jeong Soh, published 2017 by ANU Press, The Australian National University, Canberra, Australia. 